\title{
Job Satisfaction and Levels of Burnout of the University Staff Who Do
} and Don't Do Sports Regularly

\author{
Mustafa Bas' , Kübra Küçük1', Cihat Kisa² \\ ${ }^{1}$ Trabzon University, Department of Sports Sciences, Trabzon, \\ Turkey \\ ${ }^{2}$ Dokuz Eylül University, İzmir, Turkey \\ Study Area: Trabzon, Turkey \\ Coordinates: $41^{\circ} \mathrm{oo} ' 18$ ? N; $39^{\circ} 43^{\prime 21}$ ? E
}

Keywords: Leisure, Sporting

\begin{abstract}
The population of the research was the university staff who work within the faculty of education. Among 51 university staff, 23 participate in sports regularly and 28 of whom don't. In the research, Personal Information Form which was developed by the researcher; Maslach Burnout Scale, the study of the validity and the "Job Satisfaction Scale was used as a data collection tool. As a result of the research; it was found out that there was a significant difference between the university staff who do and don't do sports regularly in terms of job satisfaction and level of burnout, in favour of those who do sports regularly. No statistical difference was found when the job satisfaction and levels of burnout of the university staff who do and don't do sports regularly according to their professional experiences.
\end{abstract}

have different expectations, needs and priorities explain the limitation of the definitions. Life satisfaction is the emotional response of the individual outside the business life. In other words, her/his general attitude towards life (Özdevecioglu, 2003).

The reason why job satisfaction has gained importance recently is that the problems, arising from the employees, gradually increase. The satisfaction of a person from her/his job has a great influence on her/his business life. In general terms, job satisfaction can be expressed as all positive or negative feelings in the work environment (Polat, 2014).

In general, satisfaction means having pleasure, having satiation from an activity, a job, an event, or an impulse. Job satisfaction is the satisfaction of the person if she/he meets the expectations, wishes, and values of the job and fulfills her/his needs. Meeting the needs in working life results in the job satisfaction of the employee (Silah, 2001).

Job satisfaction can be def ined as "the expression of the satisfaction or positive emotions of the employee when her/his work or experience are evaluated".

Whether the employee is satisfied with her/his job, colleagues, managers, wages, progress opportunities, and working conditions or not, directly affects her/his work. Generally, personnel who is satisfied with these situations; will have an increased level of job satisfaction due to a high level of morale and thus, the personnel will be more productive and creative. Otherwise, while the employee's level of morale and job satisfaction will be low and the quantity and quality of the job will be adversely affected, the peace and working tempo of their colleagues will be 
negatively affected (Budak, 2006).

Burnout can be defined as the result of continuous excessive stress in the workplace that occurs when there is an unbalance between the work demands and personal capacity within a long period of time. Energy depletion, increase in the mental recession from the work, decrease in professional performance are among the most important characteristics of many burnout factors (Kalimo, 2003).

A person suffering from burnout thinks that life has lost its meaning and all her/his desires have disappeared. Her/his occupations which were previously meaningful to her/him, have become boring and show no importance. These individuals have behaviors that are strange, angry, strict, and closed to suggestions and act in a way that pushes people. The person with burnout is in a state of exhaustion and disappointment due to the inability to achieve what she/he expects from a relationship or lifestyle that she/he got used to (Dericiogullari, 2007).

The burnout increasingly shows its effects by exceeding the fighting power of the employees in a stressful work environment. It is a situation that brings the workers into a self-enclosed situation. In the event that the burnout occurs, it will not only affect the individuals but also the phenomenon of burnout will turn into a psychological and social situation (Çam, 2001).

In this study, it is aimed to better understand the benefits of doing sport regularly by determining the differences in the job satisfaction and burnout levels of the university staff who do and don't do sports regularly and to shed light on the individuals working in different institutions.

\section{Methodology:}

The research was carried out in a screening model. Screening models were the research approaches that were conducted on a sample group selected from a population that includes large groups and that aim to examine a past or present situation as it existed. The event, individual, or object, which were the subjects of the research, are tried to be defined in their own conditions and as they exist. They are not attempted to be changed or influenced in any way. The thing which is intended to be known exists and is there. The important thing is to be able to observe and identify them in an appropriate way (Karasar, 2005).

The population of the research consisted of all the university staff who work within the Fatih Faculty of Education of Karadeniz Technical University, and its sample has consisted of totally 51 university staff who voluntarily accepted to participate in our study, 23 of whom do sports regularly and 28 of whom don't. In the collection of the data; Personal Information Form which was developed by the researcher, Gödelek (1988) which was developed by Hackman \& Oldham (1980), the "Job Satisfaction Scale which was developed by Güler (1990) and Maslach Burnout Scale which were developed by Maslach were used. It is the most widely used scale for the evaluation of burnout syndrome. It has consisted of twenty-two articles. Each article is given a point between 0-5. It has consisted of three subscales that the three dimensions of the burnout syndrome defined by Maslach: emotional exhaustion (EE), depersonalization (DP), and personal success (PS). The individuals who have burnout are expected to have higher emotional exhaustion and depersonalization points and lower success point. The scale and its subscales do not have a cut-off point. The study of validity was conducted by Erin (Ebrinç et al., 2002). In this study; Cronbach's alpha value was calculated as 89 , desensitization sub-dimension as 86 , and personal success sub-dimension as 85 . In the analysis of the research data, SPSS 21,0 statistics program was used. T-Test and One Way Anova tests were used in the analysis and interpretation of the data. The significance level was taken as $\mathrm{p}<0.05$.

\section{Results:}

Results are summerized in table- 1 \& 2 .

Table 1. T-Test results of the participants who do and don't do sports regularly

\begin{tabular}{llllll}
\hline Variables & \multicolumn{2}{l}{ Regular $\mathrm{n}$} & Avrg. & Ss & $\mathrm{P}$ \\
\hline Job Satisfaction & Yes & 23 & 3.66 & 0.59 & .001 \\
& No & 28 & 3.75 & 0.71 & .003 \\
Emotional Exhaustion & Yes & 23 & 5.83 & 0.48 & .000 \\
& No & 28 & 17.15 & 9.11 & .005 \\
Desensitization & Yes & 23 & 4.53 & 3.24 & .000 \\
& No & 28 & 9.25 & 4.89 & .003 \\
Personal Success & Yes & 23 & 24.36 & 3.92 & .000 \\
& No & 28 & 18.81 & 5.60 & .000 \\
\hline
\end{tabular}

Table 2. One way anova test results of university staff by their period of work

\begin{tabular}{lllllll}
\hline Varibales & $\begin{array}{l}\text { Period } \\
\text { of Work }\end{array}$ & $\mathrm{n}$ & Avrg. & Ss & F & P \\
\hline Job Satisfaction & $1-5$ yrs & 10 & 3.12 & 0.49 & 0.24 & .55 \\
& $6-10$ yrs & 7 & 2.96 & 1.01 & & \\
& $11-15$ yrs & 21 & 3.02 & 0.74 & & \\
& $\geq 16$ yrs & 13 & 2.81 & 0.69 & & \\
& Total & 51 & 3.05 & 0.71 & & \\
Emotional & $1-5$ yrs & 10 & 8.97 & 6.13 & 1.00 & .26 \\
& $6-10$ yrs & 7 & 12.70 & 10.28 & & \\
& $11-15$ yrs & 21 & 13.01 & 10.33 & & \\
& $\geq 16$ & 13 & 11.62 & 8.06 & & \\
Desensitization & Total & 51 & 11.85 & 9.42 & & \\
& $1-5$ yrs & 10 & 4.92 & 3.23 & 2.19 & .06 \\
& $6-10$ yrs & 7 & 8.15 & 4.96 & & \\
& $11-15$ years21 & 7.88 & 5.19 & & \\
& $\geq 16$ yrs & & 13 & 5.63 & 3.26 & \\
& Total & 51 & 6.24 & 4.15 & \\
\hline
\end{tabular}

As per the period of work in the profession, there is not a significant difference in job satisfaction, emotional exhaustion, desensitization and personal success points. 


\section{Discussion and Conclusion:}

It has been understood in our research that the university staff who do sport regularly are better on subjects such as job satisfaction, emotional exhaustion, desensitization, and personal success and that there is a significant difference between the staff who do and don't do sports regularly, in favor of the ones who do sports regularly.

Özen \& Uzun (2005) conducted social support research about the work and family conflict on the female and male police staff working in Mugla Police Department and found that men feel themselves more tired than women, these situations prevent their personal responsibilities at home more than women, and due to the fact that men's minds are more engaged in jobs that women, their work has a negative impact on their family life responsibilities (Sisman \& Topgül, 2013). Since the whole sample group consisted of males, the data belong to men only. Today, it is common for men to take a more active role in working life and especially university staff to face continuous student problems and other employees 'problems such as mental and physical fatigue, exhaustion and nervousness negatively affect individuals' job satisfaction and burnout.

In the study regarding the examination of the attitudes of the university faculty members towards the sport and life and job satisfaction levels, sports habits conducted by Birol \& Süleyman (2003), while there was a significant difference between the economic levels and status of life and job satisfaction levels of the teaching staff, no signif icant difference between the levels of doing sports was seen. The percentage of doing sports of the faculty members, whose life and satiety levels are high, was also found high. $80.1 \%$ of the faculty members engaged in sports stated that when they do sports, they move away from daily problems. 90.4\% of the people doing sports used the phrase "pore makes me relax psychologically" (Birol \& Süleyman, 2003). As it is understood from this research, it contributes to the positive satisfaction of job satisfaction levels of individuals doing regular sports.

When the results of the analysis of the university staff according to the period of work in the profession were examined in the study, it was found that job satisfaction, emotional exhaustion, desensitization, and personal success points did not show signif icant differences. We can say that the reason for this is that the working conditions and working hours of the university staff are close to each other.

As a result, the fact that the job satisfaction and burnout levels of the university staff doing sports regularly poses a statistical difference when compared to the ones who don't do sports regularly is a certainty that the regular sports result from the physical, psychological and social benefits provided to the individual. Sports is a phenomenon that affects the lives of individuals positively and makes positive contributions to society, family, environment, and business life. In the age of technology, people meet their needs effortlessly and this leads to a static life. In our research, the fact that job satisfaction and burnout status of university staff who do regular sports differ statistically positive in comparison to the staff who don't do sports can be explained as a natural result of doing sports regularly. From this result, the university staff should be encouraged to do sports as regularly as possible and should be explained the benefits of sports.

\section{References:}

Birol, D. \& Süleyman, M. (2003): Examination of the Attitudes of the University Faculty Members Towards Sport, Life and Work Satiety Levels and Sports Habits. Ege University School Of Physical Education And Sports, Post Graduate Thesis.

Budak, E. (2006): Job satisfaction level of public sector employees, An Application in Ministry of National Defense Fuel Supply and Nato Pol Facilities. Anadolu University Institute Of Social Sciences, Post Graduate Thesis, Eskisehir. p.4.

Çam, O. (2001): Investigation of Validity and Reliability of Burnout Inventory. Scientific Studies of VII. National Psychology Congress, Ankar, Turkey.

Dericiogullari, A., Konak. S., Arslan, E. \& Öztürk, B. (2007): Burnout levels of academic staff: sample of mehmet akif ersoy university. Firat Health Care Ser. J., 2:13-21.

Ebrinc, S., Acikel, C., Basoglu, C., Cetin, M. and Celikoz, B. (2002) Anxiety, Depression, Job Satisfaction, Burnout and Coping with Stress in Nurses of a Burn Unit: A Comparative Study. Anatol.J. Psychiat., 3:162-168

Heller, D., David, W. \& Remus, I. (2001): The role of person vs. situation in life satisfaction critical examination. Psychol. Bull., 130(4):574-600.

Kalimo, R. \& Pahkin, W. (2003): Mutanen Pertti. Toppinen-Tanner Salla. Staying wellor burning out at work, Workc Haract eristics and Personal Resour Cesaslong-termp Redictors. Work Stress, 17(2):109.

Karasar, N. (2005): Scientific research method. (15. Edition). Pub. by: Ankara: Nobel Publication Distribution.

Maslach, C. (1982): Burnout The Cost of Coring: Neus Jensey Prantich. Health J., 12:99-113.

Özdevecioglu, M. (2003): A Research on Determining the Relationship Between Job Satisfaction and Life Satisfaction. 11th National Congress of Management and Organization, Afyon.

Özer, M.Ö. (2003): Life satisfaction in the elderly. Turk. J. Geriatrics, 6(2):72-74.

Opinions on Providing It: A Research on the Police working in Eskisehir City Center. Tunceli Uni.J. Social Sci., 1(2):197.

Sisman, Y. \& Topgül, S. (2013): The Balance Between Work And Family Life Of Police Off icers. L. Organ. Behav.,10:15-23 